\title{
Thrombolytic therapy for acute stroke in Mexico: Experience of four Mexican hospitals
}

\author{
Antonio Arauz ${ }^{1 *}$, Beatriz Mendez¹, Eduardo Soriano-Navarro ${ }^{1}$, Angélica Ruiz-Franco², Jimena Quinzaños ${ }^{3}$, \\ Marlene Rodríguez-Barragán ${ }^{3}$, Erick García-Valadez ${ }^{4}$, and Fernando Góngora-Rivera ${ }^{4}$ \\ ${ }^{1}$ Stroke Clinic, Instituto Nacional de Neurología y Neurocirugía Manuel Velasco Suarez; ${ }^{2}$ Stroke Clinic, Hospital Juárez de México; ${ }^{3}$ Neurorehabilitation \\ Clinic, Instituto Nacional de Rehabilitación; ${ }^{4}$ Stroke Unit, Hospital Universitario José Eleuterio González, Universidad Autónoma de Nuevo León, \\ Monterrey, Nuevo León. Mexico City, Mexico
}

\begin{abstract}
Background: Although the efficacy of intravenous thrombolysis (IV-T) has been widely demonstrated, the rates of its use continue to be low. Purpose: The purpose of this study was to assess the frequency of IV-T in Mexican hospitals and to describe the target times for acute treatment and the functional evolution of patients. Methods: Data prospectively collected from patients with acute ischemic stroke treated over a period of 2 years in four Mexican hospitals were analyzed. We assessed demographic data, the onset-to-door (OTD) time, the door-to-needle (DTN) time, treatment and the National Institutes of Health Stroke Scale (NIHSS), and modified Rankin scale (mRs) scores at the baseline and at the end of the follow-up. Results: There were 500 patients (mean age $57 \pm 14$ years, 274 [55\%] men). The median OTD time was $11 \mathrm{~h}$ (range $30 \mathrm{~min}-190 \mathrm{~h}$ ); the mean of NIHSS score was $10 \pm 6$. Eighty-seven (17.4\%) patients arrived at the hospital within $4.5 \mathrm{~h}$; but only $38(7.6 \%)$ patients were treated with IV-T (mean of NIHSS $12 \pm 6$ points; with a mean OTD time of $2.1 \mathrm{~h}$ and a DTN time of $82 \pm 51 \mathrm{~min}$ ). After a median follow-up of 6 months (range 5-24 months), the final NIHSS score was $7 \pm 6$ points. A better prognosis was observed ( $m R s<2)$ in patients who received IV-T $(p=0.04)$. Conclusions: The frequency of IV-T in Mexican hospitals continues to be $<10 \%$. A high percentage of patients continues to arrive at the hospital outside the therapeutic window.
\end{abstract}

Key words: Acute ischemic stroke. Intravenous thrombolysis. t-PA. Cerebral infarction. Acute.

\section{Terapia trombolítica para el infarto cerebral agudo en México: experiencia de cuatro hospitales Mexicanos}

\section{Resumen}

Antecedentes y objetivo: Aunque la eficacia de la trombólisis intravenosa (T-IV) está ampliamente probada, las tasas de uso continúan siendo bajas. Nuestro objetivo fue valorar la frecuencia de T-IV en hospitales mexicanos, describir los tiempos meta de tratamiento agudo y la evolución funcional de los pacientes. Pacientes y métodos: Los datos demográficos, tiempos de llegada al hospital; puerta aguja (TP-A) y el tratamiento empleado de pacientes con infarto cerebral agudo (ICA) y

\footnotetext{
Correspondence:

*Antonio Arauz

Stroke Clinic

Instituto Nacional de Neurología y Neurocirugía

Manuel Velasco Suarez

Date of reception: 12-07-2019

Date of acceptance: 22-07-2019

E-mail: antonio.arauz@ prodigy.net.mx

DOI: 10.24875/RMN.19000112

Available online: $30-10-2019$

Rev Mex Neuroci. 2019:20(5):210-213

www.revmexneurociencia.com

1665-5044/@ 2019. Academia Mexicana de Neurología A.C. Published by Permanyer México. This is an Open Access article under the terms of the CC BY-NC-ND license (http://creativecommons.org/licenses/by-nc-nd/4.0/).
} 
tratados en 4 hospitales mexicanos fueron recolectados en registros prospectivos de enero de 2017 a enero de 2019 . La gravedad y discapacidad se midieron por la escala de NIH y la escala modificada de Rankin (emR). Resultados: Analizamos 500 pacientes (media de edad $57 \pm 14$ años; 274 (55\%) hombres). La mediana de tiempo entre el inicio de los síntomas y la llegada al hospital fue de $11 \mathrm{~h}$ (rango de 0.30 a $190 \mathrm{~min}$ ). La media de NIHSS fue de $10 \pm 6$ puntos. 38 (7.6\%) pacientes recibieron T-IV (media de NIHSS $12 \pm 6$ puntos). En los tratados con T-IV la media de tiempo del inicio de síntomas a la llegada al hospital fue de $2.1 \mathrm{~h}$ (127 min) y el TP-A tuvo una media de $82 \pm 51 \mathrm{~min}$. Después del seguimiento el NIHSS final fue de $7 \pm 6$ puntos. Se observo un mejor pronóstico $(e m R<2)$ en pacientes que recibieron $t-I V(p=0.04)$. Conclusiones: La frecuencia de T-IV continúa siendo menor al 10\%. Un porcentaje elevado de pacientes continúa llegando al hospital fuera de ventana terapéutica.

Palabras clave: Agudo. Infarto cerebral. Terapia trombolítica. t-PA. Trombólisis.

\section{Introduction}

Intravenous thrombolysis with tissue plasminogen activator (IVtPA) has improved dramatically overtime and is strongly associated with a good functional outcome. However, its benefit is time dependent with no clear benefit beyond $4.5 \mathrm{~h}$ after the time of onset ${ }^{1,2}$. Despite some initiatives of Mexican medical societies and the recommendations of the different international guidelines, in Mexico, a substantial portion of patients do not receive IV thrombolysis or thrombectomy ${ }^{3}$. For clinicians, administrators and decision makers who seek to improve the treatment and prognosis of patients with stroke, it is important to know the current situation of acute stroke treatments, as it will allow the implementation of activities and programs that help to reduce the consequences of this devastating disease.

Our objective was to evaluate the frequency of IV thrombolysis in Mexican hospitals with the capacity to administer this treatment. In addition, we assessed the onset-to-door (OTD) and door-to-needle time in treated patients and their association with the clinical outcomes.

\section{Methods}

Four participating hospitals in Mexico (Instituto Nacional de Neurología [INNN], Instituto Nacional de Rehabilitacion [INR], Hospital Juárez de México [HJM], and Hospital Universitario de Nuevo León [HUNL]) contributed with prospectively collected data from consecutive ischemic stroke patients. The participating centers each have an institutional stroke program for acute care and subsequent follow-up and were recruited through formal invitation due to their known work in stroke care. Data were used primarily at the local site for epidemiological reasons; therefore, the sites were granted waivers for informed consent. The Institutional Ethics Committee of the INNN approved the stroke dataset according to international and local research regulations.
The population consisted of patients with acute ischemic stroke (AIS) treated in participating hospitals from January 2017 to January 2019. Patient data including demographics, medical history, stroke onset (defined as the last known time, at which the patient was well), arrival time (OTD), tPA treatment initiation time (door-to-needle [DTN] time), in-hospital mortality, and ambulatory status at discharge were extracted by trained hospital personnel. Stroke severity was measured by the National Institute of Health Stroke Scale (NIHSS) and the functional outcome was measured by the modified Rankin scale (mRS).

The diagnosis of ischemic stroke was verified by a trainer stroke neurologist and we analyzed data from all patients with a primary stroke diagnosis of ischemic stroke during the study period. Although treatment with thrombectomy is possible in three of the hospitals, only cases treated in one of the hospitals were reported, so for the purpose of the present report, only patients treated with IVtPA were included in the analysis.

To describe patient characteristics, we summarized and compared two groups: patients treated with IVtPA and patients not treated with IVtPA. We analyzed the OTD time in both groups and the DTN time in those treated with IVtPA.

Statistical analyses were performed with SPSS version 19. We performed a descriptive analysis of the different variables, expressed in proportions, medians, and ranges. The proportions of patients with a DTN time of $60 \mathrm{~min}$ and clinical outcomes were compared between patients treated with and without tPA.

\section{Results}

We analyzed 500 patients (207 from HUNL, 172 from HJM, 92 from INNN, and 29 from INR). The mean age of the population was $57 \pm 14$ years and 274 (55\%) were men. The most frequent risk factors were hypertension in 225 (54\%), diabetes in 177 (37\%), and 


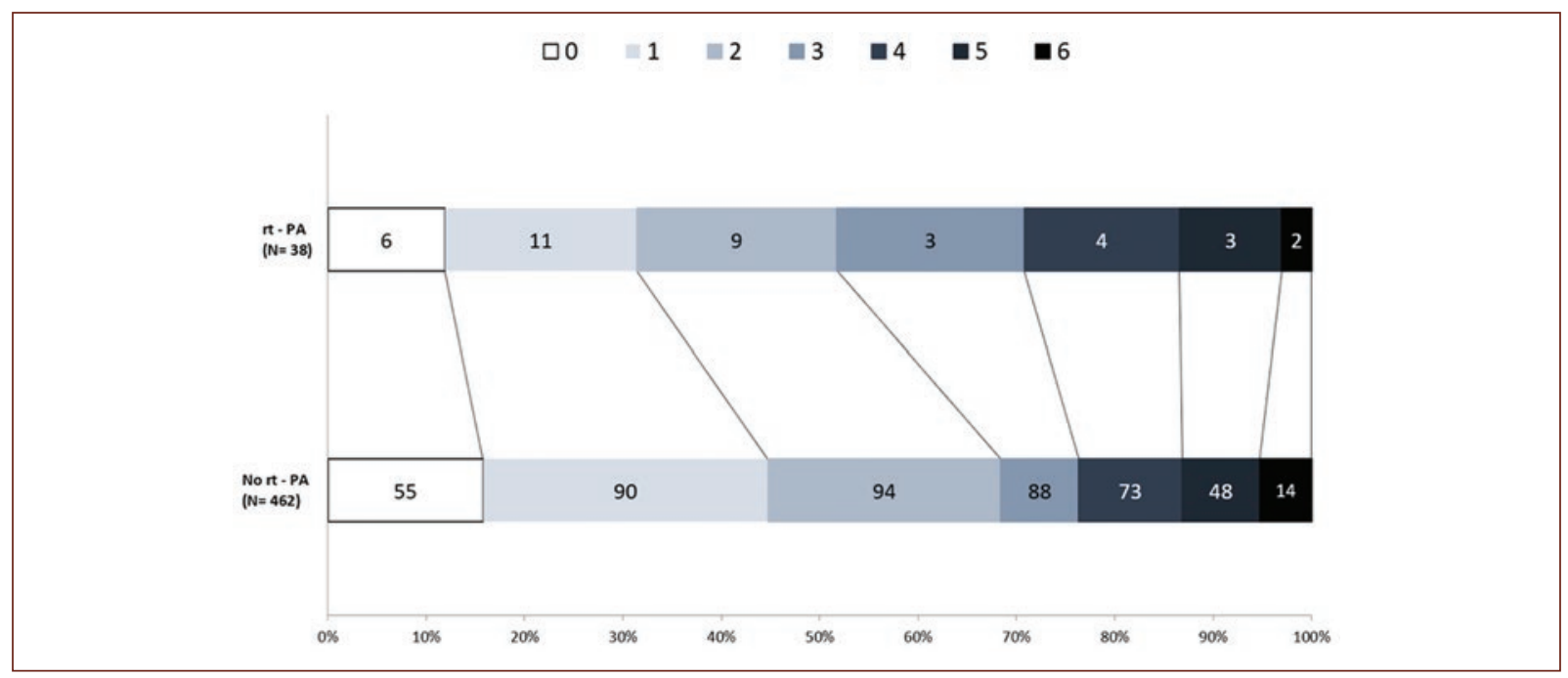

Figure 1. Difference of modified Rankin score scale in groups of patients with and without the use of intravenous thrombolysis with tissue plasminogen activator.

tobacco use in 149 (31\%). The mean NHISS score was $10 \pm 6$ points.

The median OTD time was $11 \mathrm{~h}$ (range: $30 \mathrm{~min}$ $190 \mathrm{~h})$. Eighty-seven (17.4\%) patients arrived at the hospital in < $4.5 \mathrm{~h}$ (median OTD $2.6 \mathrm{~h}$, range $50 \mathrm{~min}$ $4.5 \mathrm{~h}$ ), but only $38(7.6 \%)$ received IVtPA (OTD time; 2.1 , range $40 \mathrm{~min}-4.2 \mathrm{~h}$ ). In patients treated with IV thrombolysis, the mean DTN time was $82 \pm 51 \mathrm{~min}$ (range $15 \mathrm{~min}-3.7 \mathrm{~h}$ ), and in 17 treated patients (44.7\%), the DTN time was longer than $60 \mathrm{~min}$.

Overall, there were $16(3.2 \%)$ in-hospital deaths, and $265(53 \%)$ patients achieved independent functional outcomes at hospital discharge. No cases of hemorrhagic complications were reported.

After a median follow-up of 6 (rages 5-24) months, $269(53 \%)$ patients evolved with good functional prognosis (mRs 0-2), $229(54 \%)$ in the group without IV thrombolysis versus $26(69 \%)$ in the treated group (Fig. 1). At the end of the follow-up, the median NIHSS scale score was 6 (range 0-34).

In the comparative analyses, 462 (92\%) patients with AIS were not treated with IVtPA, of whom $51 \%$ had poor functional outcomes (mRS 3-6). A trend toward better functional outcomes was observed in patients who received IVtPA $(p=0.04)$.

\section{Discussion}

This study found that the majority of patients with AIS fail to present to the hospital within the optimal time period for effective intervention. The time of arrival at the hospital after the onset of symptoms was widely variable, ranging from $30 \mathrm{~min}$ to $190 \mathrm{~h}$. Because it was not the objective of the study, we did not analyze what were the causes of the delay, but it could be explained by the failure to recognize the signs and symptoms or a lack of awareness of potential treatment benefits. Hospitals also failed to have an adequate organization for the treatment of these patients; among those who arrived within the therapeutic window, less than half received treatment with IPA and in more than half the patients who were treated, the DTN time was $>60 \mathrm{~min}$, with a wide range.

The lack of improvement in the delay in stroke evaluation and treatment underscores the need for more effective public health programs in Mexico. Further, efforts to increase public awareness of stroke signs and symptoms, to disseminate guidelines and recommendations for stroke evaluation and treatment, and to develop initiatives (including those targeting health-care providers, the emergency medical system, telemedicine, those implementing a pre-hospital acute stroke protocol and the public) are imperative to change this scenario in Mexico and in most other middle- and low-income countries.

In positive trials, patients were treated at hospitals with complex, efficient, resource-rich, team-based stroke systems in place, in which the implementation of a national quality improvement initiative was associated with improved timeliness of IPA administration, and this improvement was associated with lower in-hospital mortality and intracranial hemorrhage ${ }^{4}$. 
Developed countries have greatly reduced mortality and dependence mainly due to changes in case fatality; however, there has been limited progress in the acute stroke management in developing countries ${ }^{5,6}$. This could be attributed to several reasons mainly relating to limited health-care resources for the population, socioeconomic considerations, pre-hospital delay, and lack of infrastructure. Although in Mexico, the use of IVtPA seems to have been increased in recent years ${ }^{2}$, its frequency of use continues to remain low, and hospital arrival and treatment times remain far below the international standards. In contrast, to our results, a previous study in Mexico showed that a high percentage of patients had short hospital arrival times; however, less than $3 \%$ underwent thrombolysis ${ }^{2}$. Three of the participating hospitals included patients in both registers, so it is significant that the percentage of patients treated with IVtPA, in these centers, increased from $3 \%$ to $7 \%$ in a period of 10 years.

While the previous studies demonstrated that educational efforts to improve the recognition of stroke symptoms have been shown to reduce the time to hospital arrival after symptom onset ${ }^{6-8}$, additional educational initiatives are still needed in Mexico.

Our study has multiple limitations. The main limitation is that it is a representative sample of two of the main cities in Mexico, and the results are biased toward urban settings with reasonably well-developed health-care systems. As in most developing countries, in Mexico, the quality of stroke care varies widely, with areas of excellence, intermixed with areas of severe need, depending on the location, socioeconomic status, education, and cultural beliefs of the region. Another limitation is that although the subjects were consecutive patients in a prospectively maintained database, the retrospective analysis does not allow the evaluation of other variables of interest, such as door-to-tomography time, and the causes of delay.

Our data provide a national perspective on acute stroke care and should inform the planning and optimization of stroke systems in Mexico to promote public awareness of the benefits of prompt stroke treatment.
The recognition of stroke warning signs and the time window during which reperfusion is therapeutically effective is undoubtedly an area of opportunity in Mexico.

\section{Conclusion}

The frequency of IV-T in Mexican hospitals continues to be less than $10 \%$. A high percentage fo patients continues to arrive at the hospitals outside the therapeutic window.

\section{Conflicts of interest}

The authors of this article do not have conflicts of interest to declare.

\section{Financing}

This article does not require funding sources, if required, would cover the costs generated from the research fund of the Stroke Clinic of the National Institute of Neurology and Neurosurgery of Mexico.

\section{References}

1. Powers WJ, Rabinstein AA, Ackerson T, Adeoye OM, Bambakidis NC, Becker K, et al. 2018 guidelines for the early management of patients with acute ischemic stroke: a Guideline for healthcare professionals from the American heart association/American stroke association. Stroke. 2018;49:e46-110.

2. McDermott M, Skolarus LE, Burke JF. A systematic review and meta-analysis of interventions to increase stroke thrombolysis. BMC Neurol. 2019;19:86.

3. León-Jiménez C, Ruiz-Sandoval JL, Chiquete E, Vega-Arroyo M, Arauz A, Murillo-Bonilla LM, et al. Hospital arrival time and functional outcome after acute ischaemic stroke: results from the premier study. Neurologia. 2014;29:200-9.

4. Mocco J, Fargen KM, Goyal M, Levy El, Mitchell PJ, Campbell BC, et al. Neurothrombectomy trial results: stroke systems, not just devices, make the difference. Int J Stroke. 2015;10:990-3.

5. Brainin M, Teuschl Y, Kalra L. Acute treatment and long-term management of stroke in developing countries. Lancet Neurol. 2007;6:553-61.

6. Xian Y, Xu H, Lytle B, Blevins J, Peterson ED, Hernandez AF, et al. Use of strategies to improve door-to-needle times with tissue-type plasminogen activator in acute ischemic stroke in clinical practice: findings from target: stroke. Circ Cardiovasc Qual Outcomes. 2017;10:e003227.

7. Kamal N, Sheng S, Xian Y, Matsouaka R, Hill MD, Bhatt DL, et al. Delays in door-to-needle times and their impact on treatment time and outcomes in get with the guidelines-stroke. Stroke. 2017;48:946-54

8. Fonarow GC, Zhao X, Smith EE, Saver JL, Reeves MJ, Bhatt DL, et al. Door-to-needle times for tissue plasminogen activator administration and clinical outcomes in acute ischemic stroke before and after a quality improvement initiative. JAMA. 2014;311:1632-40. 